\title{
TP53 mutation in newly diagnosed acute myeloid leukemia and myelodysplastic syndrome
}

Pimjai Niparuck', Pornnapa Police ${ }^{1}$, Phichchapha Noikongdee ${ }^{1}$, Kanchana Siriputtanapong ${ }^{1}$, Nittaya Limsuwanachot ${ }^{2}$, Budsaba Rerkamnuaychoke ${ }^{2}$, Suporn Chuncharunee ${ }^{1}$ and Teerapong Siriboonpiputtana ${ }^{2^{*}}$

\begin{abstract}
Objectives: TP53 mutation is found frequently in therapy related acute myeloid leukemia (AML)/ myelodysplastic syndrome (MDS), AML and MDS patients with monosomy or complex karyotype. However, the prevalence and treatment outcome in TP53 mutated AML/MDS patients in Asian population are scarce. We therefore conducted this study to analyze the prevalence and the treatment outcomes of TP53 mutation in AML and MDS-EB patients.

Methods: Patients with newly diagnosed AML and MDS-EB were recruited, extraction of deoxyribonucleic acid from bone marrow samples were done and then performing TP53 mutation analysis, using MassArray ${ }^{\circledR}$ System (Agena Bioscience, CA, USA).
\end{abstract}

Results: A total of $132 \mathrm{AML} / \mathrm{MDS}$ patients were recruited, patients with de novo AML, secondary AML, MDS-EB1, MDS-EB2 and T-AML/MDS were seen in 66, 13, 9, 9 and 3\%, respectively. TP53 mutation was found in 14 patients (10.6\%), and prevalence of TP53 mutation in T-AML/MDS, secondary AML, de novo AML and MDS-EB patients were 50, 17.6, 9.2 and 8\%, respectively. Three patients had double heterozygous TP53 mutation. Mutated TP53 was significantly detected in patients with monosomy and complex chromosome. Common TP53 mutation were R290C, T220C, A249S and V31I which V31I mutation was reported only in Taiwanese patients. Most variant allele frequency (VAF) of TP53 mutation in the study were greater than 40\%. Three year-overall survival (OS) in the whole population was 22\%, 3y-OS in AML and MDS-EB patients were 22 and 27\%, respectively. The 1y-OS in patients with TP53mutant AML/MDS were shorter than that in TP53 wild-type patients, $14 \%$ versus 50\%, $P=0.001$. In multivariate analysis, factors affecting OS in $132 \mathrm{AML} / \mathrm{MDS}$ patients was mutant TP53 $(P=0.023, \mathrm{HR}=1.20-7.02)$, whereas, WBC count $\geq 100,000 / \mu \mathrm{L}(P=0.004, \mathrm{HR}=1.32-4.16)$ and complex karyotype $(P=0.038, \mathrm{HR}=1.07-9.78)$ were associated with shorter OS in AML patients.

Discussion: In this study, the prevalence of TP53 mutation in de novo AML and MDS-EB patients were low but it had impact on survival. Patients with monosomy or complex karyotype had more frequent TP53 mutation.

Keywords: TP53 mutation, Acute myeloid leukemia, Myelodysplastic syndrome, T-AML/MDS, complex karyotype, monosomy

\footnotetext{
*Correspondence: teerapong.sir@mahidol.ac.th

${ }^{2}$ Human Genetics Laboratory, Department of Pathology, Ramathibodi Hospital, Mahidol University, Bangkok, Thailand

Full list of author information is available at the end of the article
}

(c) The Author(s). 2021 Open Access This article is licensed under a Creative Commons Attribution 4.0 International License, which permits use, sharing, adaptation, distribution and reproduction in any medium or format, as long as you give appropriate credit to the original author(s) and the source, provide a link to the Creative Commons licence, and indicate if changes were made. The images or other third party material in this article are included in the article's Creative Commons licence, unless indicated otherwise in a credit line to the material. If material is not included in the article's Creative Commons licence and your intended use is not permitted by statutory regulation or exceeds the permitted use, you will need to obtain permission directly from the copyright holder. To view a copy of this licence, visit http://creativecommons.org/licenses/by/4.0/ The Creative Commons Public Domain Dedication waiver (http://creativecommons.org/publicdomain/zero/1.0/) applies to the data made available in this article, unless otherwise stated in a credit line to the data. 


\section{Introduction}

TP53 is located on chromosome site $17 \mathrm{p} 13$, the p53 protein is an important role in impeding cell cycle progression and induction of apoptosis. The loss or mutation of TP53 promotes the development of cancer including acute myeloid leukemia (AML) and myelodysplastic syndrome (MDS). The prevalence of TP53 mutation in de Novo AML, secondary AML, MDS-EB and therapy related AML/MDS (T-AML/MDS) are 5-10\%, 4\%, 15$60 \%$ and $30-50 \%$, respectively [1-8]. Whereas, the TP53 mutation has been found in 9.4, 55 and 77\% of MDS patients, MDS patients with complex karyotype and MDS patients with monosomy, respectively [7, 8]. Many various types of TP53 mutation have been reported in AML/MDS patients, nevertheless, the common TP53 mutations are located in the codon 175, 220, 248 and $273[9,10]$. The correlation between variant allele frequency (VAF) of TP53 mutation and treatment outcome was previously reported that mutated TP53 with VAF > $40 \%$ had median overall survival of 124 days and VAF < $20 \%$ was not associated with complex karyotype and treatment outcome such as complete remission (CR) rate, overall survival (OS) or event free survival (EFS) rate $[11,12]$. Moreover, according to a recent study by Bernald et al. that illustrates the treatment outcome is similar between monoallelic TP53 mutation and TP53 wild-type MDS patients, which monoallelic and biallelic TP53 mutation are found in one-third and two-third of MDS patients, respectively [13]. Currently, there are few clinical data about TP53 mutation in patients with AML and MDS with excess blasts (MDS-EB) in Asian countries $[2,6]$. Hence we conducted this retrospective study to analyze the prevalence and the treatment outcomes of TP53 mutation in AML and MDS-EB patients.

\section{Materials and methods \\ Patients and samples}

Bone marrow deoxyribonucleic acid (DNA) samples from 132 consecutive patients with newly diagnosed AML and MDS-EB during May 2014-April 2018 were used for performing TP53 mutation analysis, using MassArray $^{\circ}$ System (Agena Bioscience, CA, USA). All AML and MDS-EB patients recruited in this retrospective study had the routine study results of nucleophosmin 1 (NPM1), FMS like tyrosine kinase (FLT3) internal tandem duplication (ITD) and CCAAT/enhancer- binding protein alpha (CEBPA) analysis.

\section{Chemotherapy protocol}

Younger AML patients (aged $<60$ years) received induction chemotherapy with intravenous (i.v.) Ara-C $100 \mathrm{mg} /$ $\mathrm{m}^{2} /$ day for 7 consecutive days together with i.v. idarubicin $12 \mathrm{mg} / \mathrm{m}^{2} /$ day for 3 consecutive days $(7+3$ regimen). Patient aged $\geq 60$ years or unfit patients were treated with
$5+2$ regimen; 5 days of i.v. Ara-C $100 \mathrm{mg} / \mathrm{m}^{2} /$ day combined with 2 days of i.v. idarubicin $12 \mathrm{mg} / \mathrm{m}^{2} /$ day. The bone marrow (BM) study was re-evaluated 28 days after induction therapy. Patients achieving $C R$ received the first cycle of consolidation chemotherapy with the same regimen as induction therapy and then followed by $3 \mathrm{cy}$ cles of IDAC or HiDAC therapy for patients aged $<70$ years.

AML patients aged $\geq 70$ years and MDS-EB patients were treated with azacitidine $100 \mathrm{mg} /$ day subcutaneously for 7 consecutive days and repeated every 4 weeks. Disease response was re-evaluated after 4-6 cycles of azacitidine. CR was defined as BM blasts $<5 \%$ with absolute neutrophil count $\geq 1000 / \mu \mathrm{L}$, platelet count $\geq 100,000 / \mu \mathrm{L}$, absence of circulating blasts and absence of extramedullary disease.

\section{Targeted genomic analyses}

MassArray ${ }^{\circ}$ System (Agena Bioscience, CA, USA) was utilized to perform targeted genomic confirmation in this study. Once the target sequence(s) were input, the software will automatically generate the set of three primers; forward, reverse \& extension primer. Primers were designed to target hotspots mutation at codon 31, $126,143,175,179,194,220,238,241,248,249,255$, 273, 280, 282, 290 and 310.

Multiplex PCR technique consisted of 3 steps;

- PCR amplification was done using polymerase chain reaction (PCR) primer mix (forward and reverse primers) at the concentration of $100 \mathrm{nM}, \mathrm{MgCl} 2$ solution, dNTP $500 \mu \mathrm{M}$, PCR buffer $1 \mathrm{x}$ concentration, PCR enzyme 0.2 unit/ $\mu \mathrm{L}$ and $10-20$ ng DNA. All to mix up to the total volume of $5 \mu \mathrm{L}$. The thermal cycles were 2 min-cycle of $95^{\circ} \mathrm{C}$ following $30 \mathrm{~s}$-cycle of $95^{\circ} \mathrm{C}, 30 \mathrm{~s}$ cycle of $56^{\circ} \mathrm{C}$, then $1 \mathrm{~min}$-cycle of $72{ }^{\circ} \mathrm{C}=45$ cycles and 5 min-cycle of $72{ }^{\circ} \mathrm{C}=5$ cycles.

- Eliminating excess dNTPs from the previous step by adding shrimp alkaline phosphatase (SAP). The protocol comprised 10X SAP buffer $0.17 \mu \mathrm{L}$, SAP Enzyme $0.3 \mu \mathrm{L}$, distilled water (HPLC grade) $1.53 \mu \mathrm{L}$, to incubate in the thermal cycles of $37^{\circ} \mathrm{C}=40 \mathrm{~min}$ following by $85^{\circ} \mathrm{C}=5$ $\min$.

- Adding a single nucleotide as the terminator bases (ddNTPs) at the 3 ' position of the extend primers. By bringing the PCR products from former step, to add with extend primer mix 0.52-1.57 $\mu \mathrm{M}$, IPLEX ${ }^{\odot}$ buffer $0.222 \mathrm{x}$, IPLEX $^{\oplus}$ terminator mix $0.222 \mathrm{x}$ and IPLEX ${ }^{\oplus}$ enzyme $0.142 \mathrm{unit} / \mu \mathrm{L}$, to make up to the total volume of $9 \mu \mathrm{L}$. The thermal cycles are; $\left[95^{\circ} \mathrm{C}=30 \mathrm{~s}+\left\{95^{\circ} \mathrm{C}=5\right.\right.$ $\left.\left.\mathrm{s} \quad+5 \mathrm{x}\left(52^{\circ} \mathrm{C}=5 \mathrm{~s}+80^{\circ} \mathrm{C}=5 \mathrm{~s}\right)\right\}\right]=40$ cycles following $72{ }^{\circ} \mathrm{C}=3 \mathrm{~min}$.

Since very small volume dispensed, either Automated Liquid Handler or Manual Dispensing was adopted by the Manufacturer's certified technician. 
- Data analysis report; to dispense the final analyze on the SpectroChip and bring in to the MassArray ${ }^{\circ}$ analyzer (Mass Spectrometry), the report generated via MassArray Typer Software.

\section{Outcome assessment}

The objectives of this study were to evaluate the prevalence of TP53 mutation in AML and MDS-EB patients, and also overall survival (OS). OS was defined as the interval between the dates of diagnosis and death.

\section{Statistical analysis}

The factors which included age, white blood cell (WBC) count, cytogenetics, TP53 and other molecular data were compared between patients with and without TP53 mutation, using Fisher's exact test. OS was calculated by the Kaplan-Meier method, difference between groups were calculated using the log-rank test for univariate analysis. Cox's Regression model was used for multivariate survival analysis. All calculations were performed using the statistical package of social sciences software, SPSS statistics version 17 (Chicago: SPSS Inc.; 2008).

\section{Results}

\section{Cytogenetic and molecular analysis}

A total of 132 patients with newly diagnosed AML/ MDS-EB were recruited into the study, and $57 \%$ of whom were male. A median age was 59 years, $48 \%$ of patients were older than 60 years. Patients with de novo AML (66\%), secondary AML (13\%), MDS-EB1 (9\%), MDS-EB2 (9\%) and T-AML/MDS (3\%) were recruited into the study. Abnormal karyotype was seen in 51\% of all AML/MDS patients that included complex karyotype $(18 \%)$, monosomy (16\%), other cytogenetic abnormalities (17\%), abnormal chromosome 3 (3\%) and isolated monosomy, $\mathrm{t}(8 ; 21)$, trisomy 8 (with a frequency of $4.5 \%$ each). NPM1 and FLT3-ITD mutations were observed in 24 and $12 \%$ of 107 AML patients, respectively. Whereas only 3 out of 25 MDS patients had mutated NPM1.

$\left(\mathrm{NPM1}^{\mathrm{mu}}\right)$, FLT3-ITD $\left(\right.$ FL3-ITD $\left.^{\mathrm{mu}}\right)$ or CEBPA $\left(\right.$ CEBPA $\left.^{\mathrm{mu}}\right)$.

In the whole study, TP53 mutation was detected in 14 patients $(10.6 \%)$, and it was often found in T-AML/MDS (50\%) and secondary AML patients (17.6\%). TP53 mutation was less frequently seen in MDS-EB including one patient with T-MDS-EB (8\%), and the rate of TP53 mutation in nineteen high risk MDS patients (R-IPSS > 3.5) was $11 \%$. Whereas the prevalence of mutant TP53 in de novo AML patients was 9.2\%.

Patients' characteristics are shown in Table 1. Median age of TP53 mutated AML/MDS patients was 66 years. In group of patients with TP53 mutation, 12 patients had abnormal karyotype which 9 of those patients had unfavorable cytogenetic risk. TP53 mutation was significantly seen in AML/MDS patients with abnormal karyotype (86\%), especially monosomy (33\%) and complex chromosome (29\%). In addition, half of AML/MDS patients with TP53 mutation had complex chromosome and $71 \%$ of whom had complex karyotype with monosomy (Table 2).

In AML patients, TP53 mutation was found in 6 out of 18 AML patients with complex karyotype and 4 out of 16 AML patients with monosomy. Co-occurring TP53 with NPM1 and FLT3-ITD mutations was detected in 2 secondary AML and 1 de novo AML patients. None of AML/MDS patients with favorable cytogenetic risk or CEBPA mutation had mutated TP53. The median WBC in twelve AML and T-AML patients with mutant TP53 were 19,200/ $\mu \mathrm{L}$ (range, 2670- 83,000/ $\mu \mathrm{L})$. The common TP53 mutations were R290C (29\%) and T220C, A249S, V31I (with a frequency of $21 \%$ each). The other codons that we found TP53 mutation were 248, 241, 238 and 282. Three patients had double heterozygous TP53 mutation. Except for mutated TP53 in codon 249 and 241, the variant allele frequency (VAF) of TP53 mutation in the remaining codons were greater than 20\%. Patients' characteristics and the types of TP53 mutation are shown in Table 2.

\section{Treatment outcomes}

Of 132 patients, 102 patients received treatment included 7/3 (72 patients), 5/2 (13 patients) and azacitidine (17 patients). Sixty-one treated patients $(60 \%)$ achieved CR and only 11 CR patients (18\%) underwent allogeneic stem cell transplantation. 3y-OS in the whole population was 22\%, 3y-OS in AML and MDS-EB patients were 22 and $27 \%$, respectively. In the whole study population, the factors affecting OS in the univariate analysis were unfavorable chromosome risk, complex karyotype, monosomy, mutant TP53 and mutant TP53 with complex chromosome or monosomy, nevertheless, only mutant TP53 $(P=0.023, \mathrm{HR}=1.20-7.02)$ was significantly associated with shorter OS in the multivariate analysis. The survival of patients with mutated TP53 and wild-type TP53 are shown in Fig. 1. Whereas, WBC count $\geq$ $100,000 / \mu \mathrm{L}$, unfavorable cytogenetic risk, complex karyotype, monosomy and TP53 mutation were significantly associated with shorter OS in patients with AML according to the univariate analysis but the multivariate analysis indicated that poorer OS was found only in AML patients with WBC count $\geq 100,000 / \mu \mathrm{L}(P=0.004$, $\mathrm{HR}=1.32-4.16)$ and complex karyotype $(P=0.038, \mathrm{HR}=$ 1.07-9.78). Parameters related to the survival of AML/ MDS patients are shown in Table 3.

\section{Discussion}

Except for secondary AML and MDS-EB groups, the prevalence of TP53 mutation in this study was similar 
Table 1 Patients' characteristics and TP53 mutation in 132 patients with AML/ MDS

\begin{tabular}{|c|c|c|c|}
\hline Factors & $\begin{array}{l}\text { Number of AML/ MDS patients } \\
\mathrm{N}(\%)\end{array}$ & $\begin{array}{l}\text { TP53 mutated patients } \\
\mathrm{N}(\%)\end{array}$ & $P$ \\
\hline Age, range $16-93$ years $(N=132)$ & & & 0.575 \\
\hline$<60$ years & $69(52.3)$ & $6 / 69(8.7)$ & \\
\hline$\geq 60$ years & $63(47.7)$ & $8 / / 63(12.7)$ & \\
\hline Disease $(N=132)$ & & & 0.003 \\
\hline De novo AML & $87(65.9)$ & $8 / 87(9.2)$ & \\
\hline Secondary AML & $17(12.9)$ & 3/17 (17.6) & \\
\hline MDS (excess blast) & $24(18.2)$ & $1 / 24(4.2)$ & \\
\hline T-AML/MDS & $4(3.0)$ & $2 / 4(50)$ & \\
\hline White blood cell count in AML patients $(N=107)$ & & & 0.563 \\
\hline$<100,000 / \mu \mathrm{L}$ & $88(82.2)$ & 12/88 (13.6) & \\
\hline$\geq 100,000 / \mu \mathrm{L}$ & $19(17.8)$ & $0 / 19(0)$ & \\
\hline Chromosome analysis $(N=132)$ & & & 0.016 \\
\hline Abnormal & $67(50.8)$ & 12//67 (17.9) & \\
\hline Normal & $65(49.2)$ & $2 / 65(3.1)$ & \\
\hline Cytogenetic risk ( $N=132)$ & & & 0.01 \\
\hline Favorable & $6(4.5)$ & $0 / 6(0)$ & \\
\hline Intermediate & $89(67.4)$ & $5 / 89(5.6)$ & \\
\hline Unfavorable & $37(28)$ & 9/37 (24.3) & \\
\hline Complex chromosome $(N=132)$ & & & 0.004 \\
\hline Yes & $24(18.2)$ & $7 / 24(29.2)$ & \\
\hline No & $108(81.8)$ & $7 / 108(6.5)$ & \\
\hline Complex with monosomy karyotype $(N=132)$ & & & 0.008 \\
\hline Yes & $14(10.6)$ & $5 / 14(35.7)$ & \\
\hline No & $118(89.4)$ & 9/118 (7.6) & \\
\hline Complex with del5/-5 or del7/-7 ( $N=132)$ & & & 0.026 \\
\hline Yes & $12(9.0)$ & 4/12 (33.3) & \\
\hline No & $120(91.0)$ & 10/120 (8.3) & \\
\hline Monosomy $(N=132)$ & & & 0.002 \\
\hline Yes & $21(15.9)$ & $7 / 21(33.3)$ & \\
\hline No & $111(84.1)$ & 7/111 (6.3) & \\
\hline Gene mutation ( $N=107$ AML patients) & & & 0.893 \\
\hline FLT3-ITD & $13(12.1)$ & 3/13 (23) & \\
\hline NPM1 & $26(24.3)$ & $3 / 26(11.5)$ & \\
\hline CEBPA & $9(8.4)$ & 0/9 (0) & \\
\hline No mutation & $80(74.8)$ & $10 / 80(12.5)$ & \\
\hline
\end{tabular}

to the previously published data [1-6]. We found high prevalence of TP53 mutation in patients with secondary AML (17\%) and low prevalence of TP53 mutation in MDS-EB patients. In this study, the prevalence of TP53 mutation in the whole MDS-EB group was lower than that seen in the previous studies, $8 \%$ versus $15-60 \%[7,8]$. Nevertheless, the rate of TP53 mutation increased to $14 \%$ in MDS-EB patients with complex karyotype. The prevalence of TP53 mutation in 19 patients with high-risk MDS was $11 \%$ compared with $15 \%$ (4 out of 26 patients) in the previous study [14]. The possible causes of low prevalence of TP53 mutation in our MDS-EB patients might be from the small number of MDS-EB patients in the study ( 25 patients), low incidence of complex karyotype (7 patients) and/or underestimate the true mutation prevalence since our PCR technique was designed to detect only multiple hotspot mutations that 
Table 2 Types of TP53 mutation and treatment outcome in 14 AML/ MDS patients

\begin{tabular}{|c|c|c|c|c|c|c|c|}
\hline No & Gender & $\begin{array}{l}\text { Age } \\
\text { (y) }\end{array}$ & Disease & Chromosome/ gene mutations & $\begin{array}{l}\text { TP53 mutation type (\% } \\
\text { variant allele frequency) }\end{array}$ & $\begin{array}{l}\text { Treatment } \\
\text { regimen } \\
\text { (status) }\end{array}$ & $\begin{array}{l}\text { Time from } \\
\text { diagnosis to } \\
\text { death (Mo) }\end{array}$ \\
\hline 1 & $\mathrm{~F}$ & 57 & T-AML & $\begin{array}{l}\text { 46,XX,del(5)(q15q33),inv.(7)(p13p22),der(11) } \\
\text { NPM1 }{ }^{\text {wt }} / \text { FLT3 }^{\text {wt }} / \text { /CEBPA }^{\text {wt }}\end{array}$ & A249S (17.7) & $\begin{array}{l}\text { untreated } \\
\text { (dead) }\end{array}$ & 0.5 \\
\hline 2 & $\mathrm{~F}$ & 68 & T-MDS (EB) & 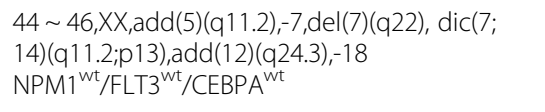 & $\begin{array}{l}\text { T220C (41.3), } \\
\text { R290C (58.7) }\end{array}$ & $\begin{array}{l}\text { azacitidine } \\
\text { (dead) }\end{array}$ & 4 \\
\hline 3 & $\mathrm{~F}$ & 64 & T-AML & 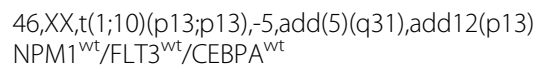 & R248W (44.3) & $\begin{array}{l}\text { untreated } \\
\text { (dead) }\end{array}$ & 3 \\
\hline 4 & M & 32 & AML & $\begin{array}{l}\text { 46,XY, del(12)(p11),i(8)(q10),der(10),del(1)(p21) } \\
\text { NPM1 }{ }^{\mathrm{wt}} / \mathrm{FLT3}^{\mathrm{wt}} / \mathrm{CEBPA}^{\mathrm{wt}}\end{array}$ & $\begin{array}{l}\text { V31I (87.3) } \\
\text { S241F (19.4) }\end{array}$ & $7 / 3$ (dead) & 5 \\
\hline 5 & $\mathrm{~F}$ & 59 & AML & $\begin{array}{l}\text { 46,XX,add19(p13.3) } \\
\text { NPM1 }^{\text {wt }} / \text { FLT3 }^{\text {wt }} / \text { CEBPA }^{\text {wt }}\end{array}$ & R290C (41.6) & $7 / 3$ (dead) & 4 \\
\hline 6 & M & 71 & AML & $\begin{array}{l}45, X Y,-10,-12,-20,+8,+9 \\
\text { NPM1 }^{\text {wt }} / \text { FLT3 }^{\text {wt }} / \text { CEBPA }^{\text {wt }}\end{array}$ & T220C (48) & $\begin{array}{l}\text { untreated } \\
\text { (dead) }\end{array}$ & 1 \\
\hline 7 & M & 43 & AML & $\begin{array}{l}\text { 42,XY,der(1)del(1)(p13p22),-3, der(5)t(5;15) } \\
\text { (q11.2;q1 1.2),-7,add(8)(q24.1),-12,- } \\
15, \text { add(8),der(8) } \\
\text { NPM1 }^{\text {wt }} / \mathrm{FLT3}^{\mathrm{wt}} / \mathrm{CEBPA}^{\mathrm{wt}}\end{array}$ & C238Y (43) & $7 / 3$ (dead) & 12 \\
\hline 8 & M & 74 & MDS-EB & $\begin{array}{l}45, X Y,-7 \\
\text { NPM1 }^{\text {wt }} / \text { FLT3 }^{\text {wt }} / \text { CEBPA }^{\text {wt }}\end{array}$ & A249S (14.2) & $\begin{array}{l}\text { azacitidine } \\
\text { (alive) }\end{array}$ & 19 \\
\hline 9 & M & 77 & $\begin{array}{l}\text { Secondary } \\
\text { AML }\end{array}$ & $\begin{array}{l}\text { 44,XY,del(3)(q21q27),-3,-12,-18,+ } 21 \\
\text { NPM1 }^{\text {mu }} / \text { FLT3-ITD }^{\text {mu }} / \text { CEBPA }^{\text {wt }}\end{array}$ & R282W (100) & $\begin{array}{l}\text { untreated } \\
\text { (dead) }\end{array}$ & 1 \\
\hline 10 & $\mathrm{~F}$ & 42 & AML & $\begin{array}{l}45, X X,-7 \\
\text { NPM1 } 1^{\text {wt }} / F_{L T} 3^{\text {wt }} / \text { CEBPA }^{\text {wt }}\end{array}$ & $\begin{array}{l}\text { T220C (52.7) } \\
\text { R290C (35.8) }\end{array}$ & $\begin{array}{l}\text { untreated } \\
\text { (dead) }\end{array}$ & 1 \\
\hline 11 & M & 42 & AML & $\begin{array}{l}47, X Y,+1 \\
\text { NPM1 }{ }^{\mathrm{mu}} / \text { FLT3-ITD }^{\mathrm{mu}} / \mathrm{CEBPA}^{\mathrm{wt}}\end{array}$ & V31I (47.7) & $7 / 3$ (dead) & 6 \\
\hline 12 & M & 68 & $\begin{array}{l}\text { Secondary } \\
\text { AML }\end{array}$ & $\begin{array}{l}46, X Y \\
N P M 1^{\text {wt }} / F L T 3^{\text {wt }} / \text { CEBPA }^{\text {wt }}\end{array}$ & V31I (23.1) & $\begin{array}{l}\text { untreated } \\
\text { (dead) }\end{array}$ & 1 \\
\hline 13 & M & 88 & AML & $\begin{array}{l}47, \mathrm{XY},+8 \\
\mathrm{NPM}^{\mathrm{wt}} / \mathrm{FLT3}^{\mathrm{wt}} / \mathrm{CEBPA}^{\mathrm{wt}}\end{array}$ & R290C (66.2) & $\begin{array}{l}\text { untreated } \\
\text { (dead) }\end{array}$ & 4 \\
\hline 14 & M & 71 & $\begin{array}{l}\text { Secondary } \\
\text { AML }\end{array}$ & $\begin{array}{l}\text { 46,XY } \\
\mathrm{NPM} 1^{\mathrm{mu}} / \mathrm{FLT}-\mathrm{ITD}^{\mathrm{mu}} / \mathrm{CEBPA}^{\mathrm{wt}}\end{array}$ & A249S (11.3) & $\begin{array}{l}\text { azacitidine } \\
\text { (dead) }\end{array}$ & 16 \\
\hline
\end{tabular}

was not the whole gene. However, the prevalence of TP53 mutation in Asian MDS and AML patients were $10.2-13 \%$ and $5.4-7 \%$, respectively $[2,15-19]$. Whereas, TP53 mutation was found in $9 \%$ of Chinese patients with MDS-EB [16]. TP53 mutation was frequently found in complex karyotype patients (42$59 \%)$ and was associated with poor overall survival in Asian patients with MDS and AML. [2, 15-19]. The prevalence, cytogenetic abnormality and prognosis of AML or MDS patients with mutated TP53 in our study were similar to the data in Asian AML/MDS patients. All TP53 mutated AML patients in the study had WBC count less than $100,000 / \mu \mathrm{L}$ and mutant TP53 was not detected in AML patients with favorable cytogenetic risk. Five out of seven de novo AML patients with TP53 mutation were younger than 60 years (range, 32-59 years), whereas, all secondary AML patients were older than 60 years. Only few patients had co-occurrence Mutations of TP53 with NPM1 and FLT3-ITD. Although the DNA probe array was designed to detect TP53 mutation covering 17 codons, we found mutation occurred in only 8 codons $(31,220,238,241,248,249,282$ and 290). We also demonstrated the uncommon patterns of TP53 mutation which occurred in codon 31 (V31I) and 249 (A249S), these two mutations have been illustrated in only few previously studies $[2,20]$. However, there was no report of these mutations in large cohort studies of AML/MDS patients in Western countries $[4,6,11,13,21,22]$. The most common type of TP53 mutation in this study was R290C (28.6\%), but interestingly, we found high prevalence of A249S and V31I mutation, which V31I mutation was observed with higher rate than the other types of TP53 mutation in Taiwanese patients with AML [2]. TP53 mutation in codon 175 and 273 were not found in our AML/MDS patients, and only 1 patient had TP53 mutation in codon 248, these 3 mutation types were commonly seen in AML patients in the previous studies $[9,10,13]$. The another common codon of 


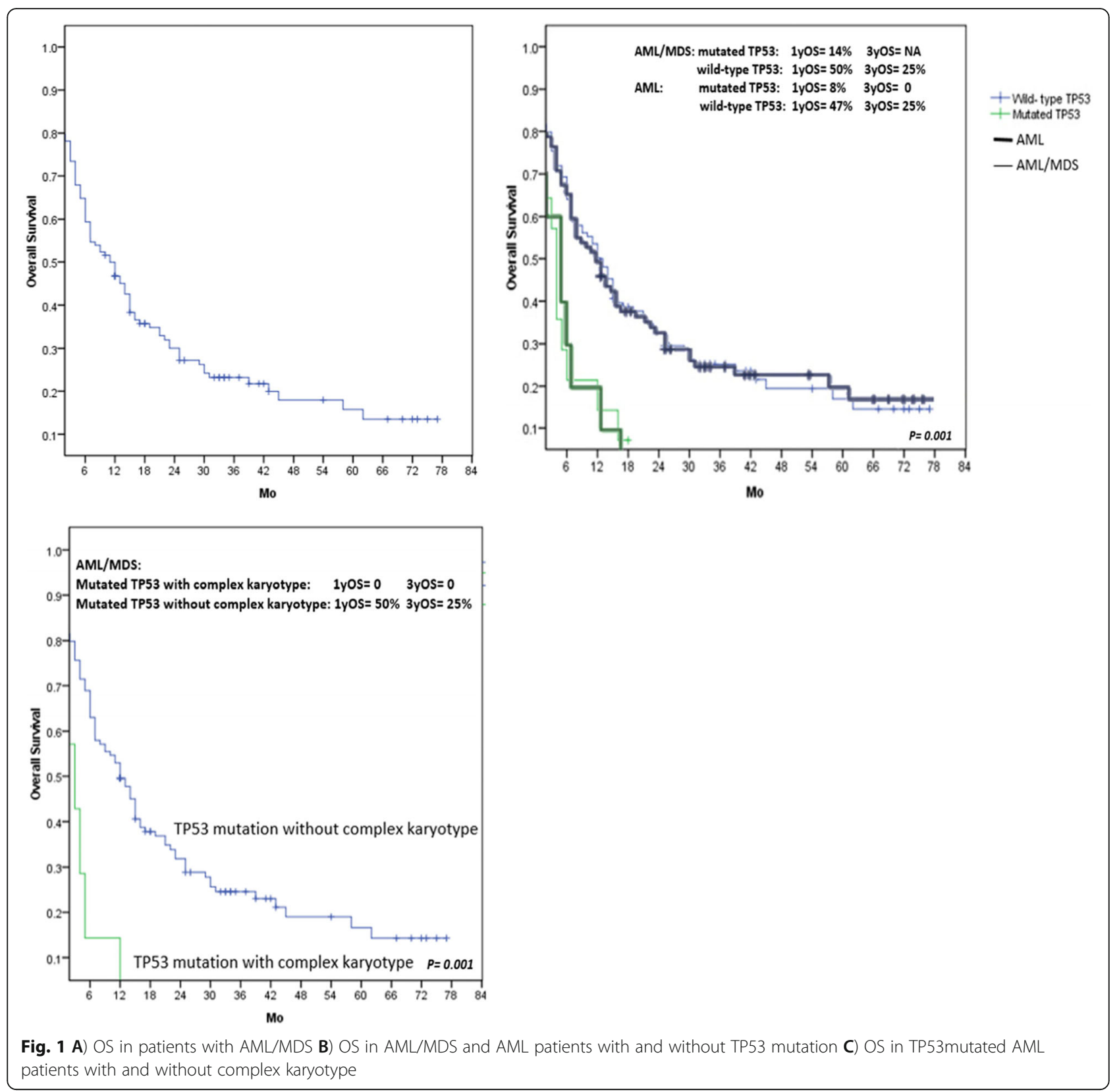

TP53 Mutation (codon 220) was also detected in our study (21.4\%) [13]. In this study, A249S was observed in patients with MDS-EB, secondary AML from MDS or T-AML but was not found in de novo AML patients, and it occurred in patients with either normal or abnormal karyotype. Whereas V31I was seen in either de novo or secondary AML, and was not associated with cytogenetic patterns. Except for TP53 mutation in codon 249 and 241, most VAF of TP53 mutation in our patients were greater than $40 \%$. The survival was significantly shorter in TP53 mutated AML/MDS patients compared with those in TP53 wild-type patients. Nevertheless, the actual survival time for patients with TP53 mutation should be longer than our TP53 mutated patients' survival since half of these patients in the study had serious infection at the time of diagnosis and didn't receive any treatment. The other limitations of this study were small number of both AML/MDS patients and TP53 mutated patients and the PCR technique was designed to detect only hotspot mutations, even seventeen mutational hotspots were sequenced. Study of whole TP53 gene mutation might increase the prevalence of TP53 mutation in our patients slightly from detection 
Table 3 Parameters affecting overall survival in 132 patients with AML/MDS

\begin{tabular}{|c|c|c|c|c|c|c|c|}
\hline AML/ MDS patients & & & & AML patients & & & \\
\hline Factors & $1 y$ - OS & $3 y-O S$ & $P$ & Factors & $1 y-O S$ & $3 y-O S$ & $P$ \\
\hline AML & 44 & 22 & 0.535 & $\mathrm{WBC}<100,00 / \mu \mathrm{L}$ & 46 & 27 & 0.014 \\
\hline MDS & 60 & 27 & & $\mathrm{WBC} \geq 100,00 / \mu \mathrm{L}$ & 28 & 0 & \\
\hline Complex karyotype & & & $<0.001$ & Complex karyotype & & & $<0.001$ \\
\hline Yes & 17 & 0 & & Yes & 6 & 0 & \\
\hline No & 54 & 29 & & No & 51 & 27 & \\
\hline Monosomy & & & 0.03 & Monosomy & & & 0.003 \\
\hline Yes & 19 & 7 & & Yes & 13 & 6 & \\
\hline No & 53 & 27 & & No & 49 & 25 & \\
\hline Complex karyotype with monosomy & & & $<0.001$ & Complex karyotype with monosomy & & & 0.001 \\
\hline Yes & 14 & 0 & & Yes & 10 & 0 & \\
\hline No & 51 & 27 & & No & 47 & 25 & \\
\hline Chromosome & & & 0.004 & Chromosome & & & 0.023 \\
\hline Favorable & 80 & 40 & & Favorable & 75 & 38 & \\
\hline Intermediate & 54 & 28 & & Intermediate & 50 & 27 & \\
\hline Unfavorable & 27 & 8 & & Unfavorable & 22 & 11 & \\
\hline TP53 & & & 0.001 & TP53 & & & 0.001 \\
\hline Mutant TP53 & 14 & NA & & Mutant TP53 & 8 & 0 & \\
\hline Wild- type TP53 & 50 & 25 & & Wild- type TP53 & 47 & 25 & \\
\hline Mutated TP53 with complex karyotype & & & 0.001 & Mutated TP53 with complex karyotype & & & 0.004 \\
\hline Yes & 0 & 0 & & Yes & 0 & 0 & \\
\hline No & 50 & 25 & & No & 46 & 23 & \\
\hline Mutated TP53 with monosomy & & & 0.138 & Mutated TP53 with monosomy & & & 0.034 \\
\hline Yes & 17 & NA & & Yes & 0 & 0 & \\
\hline No & 48 & 24 & & No & 45 & 23 & \\
\hline
\end{tabular}

Abbreviation: $N A$ not available

of other uncommon TP53 mutations. Finally, the MassArray technique would be useful for routine screening TP53 mutation in AML/MDS patients in the medical center that the next generation sequencing is not available and the cost of this testing is not high.

\section{Conclusion}

The prevalence of TP53 mutation in de novo AML and MDS-EB patients were low but it had impact on survival. Patients with monosomy or complex karyotype had more frequent TP53 mutation.

\section{Abbreviations}

MDS-EB: MDS with excess blasts; T-AML: Therapy related AML; T-

MDS: Therapy related MDS; FLT3-ITD: FMS related tyrosine kinase 3-internal tandem duplications; NPM1: Nucleophosmin1; CEBPA: CCAAT/enhancer binding protein a gene

\section{Acknowledgements}

We would like to thank all patients who participated in the study. We would like to thank Ramathibodi Comprehensive Cancer Center, Ramathibodi Hospital, Mahidol University for providing research funding.

\section{Authors' contributions}

PN designed the study, collected the cytogenetic, molecular and clinical data, analyzed the data, and wrote the manuscript. PP, PN and NL performed molecular study. KS collected the clinical data. BR and SC carried out the experiment. TS designed the study, analyzed the data and edited the manuscript. All authors read and approved the final manuscript.

\section{Funding}

This work was supported by Ramathibodi Comprehensive Cancer Center, Ramathibodi Hospital, Mahidol University.

\section{Availability of data and materials}

Not applicable.

\section{Declarations}

Ethics approval and consent to participate

This retrospective study was approved by the Local Ethics Committee on Human Rights related to research involving human subjects at Ramathibodi Hospital, Mahidol University.

\section{Consent for publication}

Not applicable.

\section{Competing interests}

The authors declare that they have no competing interests. 


\section{Author details}

'Division of Hematology, Department of Medicine, Ramathibodi Hospital, Mahidol University, Bangkok, Thailand. ${ }^{2}$ Human Genetics Laboratory, Department of Pathology, Ramathibodi Hospital, Mahidol University, Bangkok, Thailand.

Received: 14 January 2021 Accepted: 19 October 2021

Published online: 31 October 2021

\section{References}

1. Rucker FG, Schlenk RF, Bullinger L, Kayser S, Teleanu V, Kett H, et al. TP53 alterations in acute myeloid leukemia with complex karyotype correlate with specific copy number alterations, monosomal karyotype, and dismal outcome. Blood. 2012;119(9):2114-21. https://doi.org/10.1182/blood-201108-375758.

2. Hou HA, Chou WC, Kuo YY, Liu CY, Lin LI, Tseng MH, et al. TP53 mutations in de novo acute myeloid leukemia patients: longitudinal follow-ups show the mutation is stable during disease evolution. Blood Cancer J. 2015;5(7): e33. https://doi.org/10.1038/bcj.2015.59.

3. Bowen D, Groves MJ, Burnett AK, Patel Y, Allen C, Green C, et al. TP53 gene mutation is frequent in patients with acute myeloid leukemia and complex karyotype, and is associated with very poor prognosis. Leukemia. 2009;23(1): 203-6. https://doi.org/10.1038/leu.2008.173.

4. Prochazka KT, Pregartner G, Rücker FG, Heitzer E, Pabst G, Wölfler A, et al. Clinical implications of subclonal TP53 mutations in acute myeloid leukemia. Haematologica. 2019;104(3):516-23. https://doi.org/10.3324/haematol.2018.2 05013.

5. Rampal R, Ahn J, Abdel-Wahab O, Nahas M, Wang K, Lipson D, et al. Genomic and functional analysis of leukemic transformation of myeloproliferative neoplasms. Proc Natl Acad Sci U S A. 2014;111(50):540110. https://doi.org/10.1073/pnas.1407792111.

6. Horiike S, Misawa S, Kaneko H, Sasai Y, Kobayashi M, Fujii H, et al. Distinct genetic involvement of the TP53 gene in therapy-related leukemia and myelodysplasia withchromosomal losses of Nos 5 and/or 7 and its possible relationship to replication error phenotype. Leukemia. 1999;13(8):1235-42. https://doi.org/10.1038/sj.leu.2401466.

7. Kulasekararaj AG, Smith AE, Mian SA, Mohamedali AM, Krishnamurthy P, Lea NC, et al. TP53 mutations in myelodysplastic syndrome are strongly correlated with aberrations of chromosome 5, and correlate with adverse prognosis. Br J Haematol. 2013;160(5):660-72. https://doi.org/10.1111/ bjh. 12203.

8. Haase D, Stevenson KE, Neuberg D, Maciejewski JP, Nazha A, Sekeres MA, et al. TP53 mutation status divides myelodysplastic syndromes with complex karyotypes into distinct prognostic subgroups. Leukemia. 2019; 33(7):1747-58. https://doi.org/10.1038/s41375-018-0351-2.

9. Vogelstein B, Lane D, Levine AJ. Surfing the p53 network. Nature. 2000; 408(6810):307-10. https://doi.org/10.1038/35042675.

10. Hunter AM, Sallman DA. Current status and new treatment approaches in TP53 mutated AML. Best Pract Res Clin Haematol. 2019;32(2):134-44. https:// doi.org/10.1016/.j.beha.2019.05.004.

11. Barbosa K, Li S, Adams PD, Deshpande AJ. The role of TP53 in acute myeloid leukemia: challenges and opportunities. Genes Chromosomes Cancer. 2019;58(12):875-88. https://doi.org/10.1002/gcc.22796.

12. Sallman DA, Komrokji R, Vaupel C, Cluzeau T, Geyer SM, McGraw KL, et al. Impact of TP53 mutation variant allele frequency on phenotype and outcomes in myelodysplastic syndromes. Leukemia. 2016;30(3):666-73. https://doi.org/10.1038/leu.2015.304

13. Bernard E, Nannya Y, Hasserjian RP, Devlin SM, Tuechler H, Medina-Martinez JS, et al. Implications of TP53 allelic state for genome stability, clinical presentation and outcomes in myelodysplastic syndromes. Nat Med. 2020; 26(10):1549-56. https://doi.org/10.1038/s41591-020-1008-z.

14. Polprasert C, Takeda J, Niparuck P, Rattanathammethee T, Pirunsarn A, Suksusut A, et al. Novel DDX41 variants in Thai patients with myeloid neoplasms. Int J Hematol. 2020;111(2):241-6. https://doi.org/10.1007/s12185019-02770-3.

15. Yu Y, Zhang T, Bao X, Wang Q, Zhang L, Hong Y, et al. Combining gene variants with clinical characteristics improves outcome prediction in Chinese patients with myelodysplastic syndromes. Leuk Lymphoma. 2020;61(4):91926. https://doi.org/10.1080/10428194.2019.1702177.
16. Xu Y, Li Y, X Q Q, Chen Y, Lv N, Jing Y, et al. Implications of mutational spectrum in myelodysplastic syndromes based on targeted next-generation sequencing. Oncotarget. 2017;8(47):82475-90. https://doi.org/10.18632/ oncotarget.19628.

17. Yoshizato T, Nannya Y, Atsuta Y, Shiozawa Y, lijima-Yamashita Y, Yoshida K, et al. Genetic abnormalities in myelodysplasia and secondary acute myeloid leukemia: impact on outcome of stem cell transplantation. Blood. 2017; 129(17):2347-58. https://doi.org/10.1182/blood-2016-12-754796.

18. Jiang Y, Eveillard JR, Couturier MA, Soubise B, Chen JM, Gao S, et al. Asian population is more prone to develop high-risk myelodysplastic syndrome, concordantly with their propensity to exhibit high-risk cytogenetic aberrations. Cancers (Basel). 2021;13(3):481. https://doi.org/10.3390/ca ncers13030481.

19. Abinaya P, Ling SH, Seah E, Ng C, Kosmo B, Yan B, et al. Clinical implications of TP53 mutations in a southeast Asian cohort of acute myeloid leukaemia patients. Clin Diagn Pathol. 2018;2(2):1-6. https://doi.org/10.15761/CDP.1 000129.

20. Xiang X, Ou Y, Wu Y. Comparison the Distinct Clinical Outcome with TP53 Mutation Status in MDS and AML: an Retrospective Study. Blood. 2019; 134(Supplement_1):5405.

21. Dutta S, Pregartner G, Rücker FG, Heitzer E, Zebisch A, Bullinger L, et al. Functional classification of TP53 Mutations in acute myeloid leukemia. Cancers (Basel). 2020;12(3):637.

22. Belickova M, Vesela J, Jonasova A, Pejsova B, Votavova H, Merkerova MD, et al. TP53 mutation variant allele frequency is a potential predictor for clinical outcome of patients with lower-risk myelodysplastic syndromes. Oncotarget. 2016;7(24):36266-79. https://doi.org/10.18632/oncotarget.9200.

\section{Publisher's Note}

Springer Nature remains neutral with regard to jurisdictional claims in published maps and institutional affiliations.
Ready to submit your research? Choose BMC and benefit from:

- fast, convenient online submission

- thorough peer review by experienced researchers in your field

- rapid publication on acceptance

- support for research data, including large and complex data types

- gold Open Access which fosters wider collaboration and increased citations

- maximum visibility for your research: over $100 \mathrm{M}$ website views per year

At BMC, research is always in progress.

Learn more biomedcentral.com/submission 